\title{
EKSISTENSI GRUP MUSIK KERONCONG DIANTARA PENGGEMAR MUSIK DANGDUT STUDI KASUS: DESA SUKOREJO KECAMATAN TEGOWANU, KABUPATEN GROBOGAN
}

\author{
Dani Nur Saputra \\ daninursaputra6@gmail.com
}

\begin{abstract}
Abstrak
Perkembangan musik keroncong di desa Sukorejo, kecamatan Tegowanu, Kabupaten Grobogan mengalami pasang surut, karena struktur masyarakat pinggir Pantai Utara Jawa yang kebanyakan menyukai musik dangdut. Kehadiran grup musik Sukmo Budaya dengan warna musik keroncong ternyata mampu menarik antusiasme masyarakat Desa Sukorejo Kecamatan Tegowanu di daerah pinggir Pantai Utara Jawa. Hal tersebut sesuai dengan data pengamatan berdasarkan fenomena yang terjadi dalam masyarakat Sukorejo kabupaten Grobogan. Penelitian ini menggunakan metode penelitian kualitatif dengan pendekatan studi kasus agar dapat secara tepat menggambarkan, mengkaji, dan menganalisa eksistensi grup musik keroncong Sukmo Budaya. Pengumpulan data diperoleh melalui observasi, wawancara, dan dokumentasi. Teknik analisis data yang dilakukan dengan cara yaitu mereduksi data, menyajikan data, dan menarik kesimpulan atau verifikasi. Hasil penelitian menunjukkan bahwa faktor pengelolaan grup, ciri khas, panggilan pentas, bentuk penyajian, tempat pentas atau panggung, tata suara, tehnik bernyanyi keroncong, penggunaan alat musik, jenis lagu keroncong dan antusias masyarakat yang mendukung eksistensi grup musik keroncong Sukmo. Selain itu temuan lain yang muncul dengan adanya eksistensi grup Sukmo Budaya ialah dampak psikis yang terlihat dari masyarakat desa yang menunjukkan respons menyenangkan sebagai bagian dari kenyamanan hidup melalui waktu luang khususnya bagi para lansia.
\end{abstract}

Kata Kunci : eksistensi, sukma budaya, musik keroncong

\begin{abstract}
Kroncong music development in the village Tegowanu, district Sukorejo, Grobogan experiencing ups and downs, because the structure of the coastal communities of North Java who most love music dangdut. Then comes the music group Sukmo Budaya with the kroncong music is able to attract enthusiastic villagers Sukorejo subdistrict of Tegowanu at North coast of Java. It is in accordance with the observations made by researchers on a phenomenon that exists in the society Sukorejo Grobogan. This research uses qualitative research methods with the case study approach because it aptly describes, examine, and analyze the existence of kroncong music group Sukmo Budaya. The collection of data obtained through observation, interviews, and documentation. Technique of data analysis performed using analysis techniques, by reducting the data, presenting of the data, and draw conclusions or verification. The results showed the existence of factors that support the existence of the kroncong music group Sukmo consists of a management group, hallmark, calls the stage, form of presentation, stage, sound, makeup, singing keroncong techniques, the use of a musical instrument, a type of kroncong songs and enthusiastic communities against band kroncong. Besides research results that appear with the existence of a group of Sukmo Budaya is the psychological impact seen from villagers indicating feelings happy as a part of well-being through leissure time especially for the elderly.
\end{abstract}

Keywords : existence, music group, kroncong music 


\section{Pendahuluan}

Perkembangan musik keroncong saat ini mendapat apresiasi yang cukup besar dari masyarakat di Indonesia. Hal ini ditunjukkan dengan adanya penggunaan musik ini sebagai hiburan masyarakat dalam berbagai acara. Masyarakat menikmati dan antusias dalam menikmati pertunjukan musik keroncong tersebut.

Besarnya antusias masyarakat terhadap keroncong dikenal sampai ke pelosokpelosok nusantara salah satunya di kabupaten Grobogan. Pada tahun 1960 oleh tiga orang tokoh pecinta musik keroncong, yaitu : almarhum Bapak Prajitno, almarhum Bapak Selamet, dan Bapak Daryono. Ketiga orang tokoh tersebut adalah penggerak utama perkembangan musik keroncong di Kabupaten Grobogan dan sekitarnya.

Dinamika perkembangan musik keroncong di wilayah Kabupaten Grobogan pun akhirnya mengerucut di sebagian wilayah Kecamatan Tegowanu, khususnya di Desa Sukorejo. Desa Sukorejo adalah salah satu desa yang terletak di sepanjang kawasan pantai Utara Jawa, tepatnya di kecamatan Tegowanu, kabupaten Grobogan provinsi Jawa Tengah, yang mana memiliki struktur masyarakat dan kesenian daerah yang beraneka ragam.

Warga daerah di kawasan Pantai Utara Jawa memliki apresiasi yang tinggi terhadap kesenian musik daerah. Kebanyakan dari mereka menyukai jenis musik dangdut, sebagai ekspresi berkesenian musik. Demikian juga dengan warga Desa Sukorejo, yang terletak di sepanjang Pantai Utara Jawa, sangat menyukai musik dangdut. Fenomena yang menarik adalah ketika grup musik keroncong Sukmo Budaya muncul dan mulai mengisi dinamika musik di Desa Sukorejo Kecamatan Tegowanu, dengan struktur masyarakat desa yang kebanyakan menyukai musik dangdut. Namun, grup musik Sukmo Budaya dapat bertahan dengan membawakan jenis musik keroncong. Hal tersebut perlu dikaji lebih lanjut karena perlu adanya literatur yang dapat menjelaskan secara teoritis bagaimana musik keroncong dapat tetap bertahan di lingkungan sosial yang di dominasi oleh musik dangdut.

Menurut Sedyawati (2006:121) dalam Ardini (2010:1) sebagai salah satu bentuk kesenian yang berkembang di masyarakat, kehadiran musik keroncong mempunyai beberapa fungsi, yaitu : fungsi pendidikan, ekonomi, hiburan, sosial.

Salah satu penyebab musik keroncong tidak eksis di industri musik adalah peran dari produser musik yang enggan untuk memunculkan atau memasarkan musik keroncong. Hal ini disebabkan karena para produser dapat membaca pasar musik bahwa musik keroncong kurang dapat diterima dan diminati oleh masyarakat Indonesia. Akibat dari kurang berminatnya para produser musik di Indonesia untuk memproduksi musik keroncong, maka musik keroncong di industri musik Indonesia dapat dikatakan nyaris musnah (Sari, 2010:25). Namun, perjalanan grup Sukmo Budaya dapat eksis dan mampu menarik antusiasme masyarakat Sukorejo kecamatan Tegowanu.

Satu-satunya grup keroncong di desa Sukorejo adalah Sukmo Budaya pimpinan bapak Muhaimin. Grup keroncong Sukmo Budaya cukup terkenal tidak hanya di desa Sukorejo, tetapi juga di kecamatan Tegowanu dan Kabupaten Grobogan. Sudah banyak event yang diisi oleh permainan musik keroncong grup Sukmo Budaya. Hal ini menarik peneliti untuk mengkaji eksistensi grup musik keroncong Sukmo Budaya di desa Sukorejo kecamatan Tegowanu.

Menurut Poerwadarminta (1998: 221) eksistensi memiliki arti adanya atau keberadaan. Keberadaan yang dimaksud dapat berupa sesuatu yang berwujud benda baik 
bersifat konkret maupun abstrak. Benda yang konkret berupa materi atau zat, sedangkan yang abstrak salah satunya tentang paradigma berpikir pada suatu kebudayaan.

Pengakuan secara kultural meliputi pengakuan dari masyarakat terhadap sesuatu karena keberadaannya terpercaya atau meyakinkan. Keberadaan musik keroncong merupakan akulturasi budaya yang perlu dikaji baik secara tehnik maupun prakteknya.

Dahulu para penyanyi keroncong menyanyi secara improvisasi, menyumbang syairsyair lagu dan sering tidak mengikuti aturan-aturan musik. Pemain musik keroncong maupun penyanyinya membawakan lagu-lagu keroncong secara hafalan dan mempelajarinya secara lisan, karena waktu itu mereka buta huruf (Kusbini 1970: 4-5). Selain itu peranakan Portugis yang berasal dari suku Ambon dan Banda yang berdomisili di Batavia tinggal berkelompok disebuah kampung yang disebut Kampung Serani yaitu terjemahan dari kata Nasrani (Kristen).

Mereka termasuk masyarakat yang memelihara musik keroncong hingga akhirnya tersebar meluas dan dikenal di seluruh daerah di Nusantara, yaitu Indonesia. Bentuk musik dari keroncong memiliki makna yang berarti ketika dimainkan ditengah-tengah masyarakat agar mereka tertarik dengan musik keroncong. Arti bentuk musik selanjutnya dijelaskan oleh Jamalus $(1998 ; 34)$ bahwa bentuk musik adalah susunan serta hubungan antara unsur-unsur musik sehingga menghasilkan suatu komposisi atau lagu yang bermakna.

Hasil penelitian Halim (2015) mengenai perkembangan keberadaan musik Keroncong Tugu di Kecamatan Koja, Jakarta Utara banyak menyampaikan tentang prestasi Keroncong Tugu yang diberikan penghormatan untuk mengisi acara-acara pesta. Salah satunya digunakan untuk mengiringi setiap acara ritual keagamaan di gereja sampai sekarang. Jenis musik inilah yang menjadi cikal bakal keroncong asli Betawi, yang kemudian dikenal dengan sebutan Keroncong Tugu.

Selain itu juga terdapat perkembangan musik keroncong di Surakarta pada era 19201970 (Neo : 2013) yaitu masuknya musik keroncong diawali oleh beberapa grup asal Jakarta yang mengadakan pementasan di kota Surakarta, seperti Lief Java dan Montecarlo lalu seniman Annie Landouw. Selanjutnya perjalanan musik keroncong di sana dipengaruhi oleh beberapa faktor yaitu kondisi sosial budaya masyarakat Surakarta yang mempunyai apresiasi yang tinggi terhadap seni, keterbukaan pemerintah Belanda terhadap seni dan budaya, banyaknya seniman berkreatifitas tinggi serta peran pemerintah dalam mendukung kesenian dan kebudayaan dengan membangun sarana hiburan dan tempat-tempat pertunjukan.

Eksistensi keroncong yang dijelaskan oleh Drijastuti (2013) bahwa eksistensi musik keroncong di industri musik Indonesia tidak terlalu menggembirakan. Artinya, di pasar $\mathrm{CD}$ dan kaset, musik keroncong sangatlah minim produksi. Terbukti beberapa produksi musik keroncong yang dijual di toko-toko $\mathrm{CD}$ ataupun kaset tidak direspon oleh masyarakat terutama kaum muda. Keberadaan musik keroncong sebagai salah satu musik tradisi sekarang ini masih eksis namun kurang diminati oleh masyarakat.

Philip (2001) juga mendukung pendapat di atas dengan menyebutkan bahwa di Jakarta atau di luar negeri, ditemukan bahwa musik tradisional dapat dikatakan sekarat atau sudah mati, apalagi didalam dalam proyek industri rekaman menunjukkan lebih rumit dan sulit ditemukan. Hal itu disebabkan oleh kurangnya pertunjukan dibanding dua puluh tahun yang lalu, tetapi mereka masih eksis walaupun diyakini bahwa jumlah jenis pertunjukan tradisional sebenarnya lebih sedikit dibandingkan masa sebelumnya. Sementara, di beberapa negara, kesenian tradisional telah sampai batas tertindas oleh 
televisi dan film, oleh band-band pop. Di beberapa wilayah Indonesia yang masih terpencil dan kental dengan tradisi kesukuannya tampak kesenian traditional merupakan sesuatu yang sangat kuat, namun ketika di kota-kota besar dan negara maju sepertinya justru menjadi sebuah kematian. Dengan demikian eksistensi sebuah kelompok musik dapat terus hidup sangat tergantung dari banyak hal.

Sejalan dengan itu, Feuerbach (abidin:2006:33) menjelaskan eksistensialisme adalah suatu filsafat yang melukiskan dan mendiagnosa kedudukan manusia yang sulit. Dalam konteks masyarakat pedesaan, eksistensialisme merupakan penekanan kembali terhadap beberapa pikiran yang terdahulu.

Eksistensialisme sebagai suatu unsur yang universal dalam segala pemikiran adalah usaha manusia untuk melukiskan eksistensinya serta konflik-konflik eksistensi tersebut, asal mula konflik tersebut, serta upaya untuk mengatasinya. Di mana saja kedudukan manusia sulit dilukiskan baik secara teologi maupun secara filsafat, baik secara puitis atau secara seni, di situlah didapatkan unsur-unsur eksistensialis.

Eksistensi menekankan kehidupan manusia untuk berintropeksi yang memunculkan kembali persoalan tentang individualitas sehingga bila dikaitkan dengan eksistensi musik keroncong itu sendiri maka grup Sukmo Budaya mampu mengintrospeksi ketidakberkembangan atau ketidakberminatan masyarakat terhadap musik keroncong.

\section{Metode Penelitian}

Penelitian studi kasus memperoleh data melalui observasi, wawancara, dan dokumentasi. Pertanyaan wawancara yang akan ditujukan kepada narasumber difokuskan untuk mencari faktor-faktor dan alasan bagaimana grup musik keroncong Sukmo Budaya masih eksis hingga saat ini di ditengah-tengah masyarakat yang sebagian besar menyukai musik dangdut.

Pengamatan akan dilakukan dengan terjun langsung mengikuti kegiatan-kegiatan seperti latihan, kegiatan pentas, dan alat-alat yang digunakan. Selain itu juga mengamati para pemain musiknya saat melakukan pementasan yaitu gaya bermain, gesture, cara berkomunikasi dengan penonton. Hal yang perlu didokumentasikan adalah latihan dan pentas grup tersebut yang menjadi kegiatan utama grup Sukmo Budaya. Sementara lokasi penelitian yang dipilih adalah di desa Sukorejo kecamatan Tegowanu, Grobogan.

Untuk kebutuhan pengumpulan data maka diperlukan beberapa nara sumber terpercaya yang meliputi, anggota grup musik Sukmo Budaya, rutin mengikuti pentas dan latihan, memahami latar belakang berkembangnya grup musik keroncong Sukmo Budaya. Sementara untuk narasumber utama adalah pengurus grup, pemimpin grup musik keroncong desa Grajegan, para pemain keroncong dan masyarakat penggemar grup musik Sukmo Budaya. Narasumber tersebut dipilih berdasarkan latar belakang sejarah grup musik keroncong dan mereka yang terlibat langsung dalam pementasan grup Sukmo Budaya. 


\section{Hasil dan Analisis}

Setiap kelompok musik di manapun memiliki cara untuk tetap bertahan dalam menghadapi persaingan musik di nusantara. Mereka mempertahankan eksistensi grup Sukmo Budaya dengan menciptakan karya yang tetap dapat dinikmati masyarakat. Keberadaan grup Sukma budaya tidak dapat dilepaskan dari masyarakat pendukungnya, Oleh karena bersifat independent maka ada beberapa factor pendukung penting seperti,

\section{Manajemen Grup}

Manajemen organisasi kelompok yang digunakan memiliki tujuan agar grup keroncong tersebut dapat tetap diterima oleh masyarakat dan eksistensinya di dunia musik tanah air tetap diakui. Melalui kaca mata manejerial maka, struktur organisasi yang dibuat harus dapat mengatur beberapa hal yang berhubungan dengan kegiatan grup keroncong Sukmo Budaya, mulai dari jadwal latihan, jadwal manggung, pengaturan pemasukan dan pengeluaran uang dan kesekretariatan.

Personil yang ada di dalam struktur organisasi grup keroncong Sukmo Budaya adalah sanak saudara sendiri, mulai dari ketua sampai anggota. Hal tersebut selaras dengan yang dikemukakan oleh Weiss (2005: 8) tentang manajemen organisasi. Sebuah managemen membutuhkan proses perencanaan, pengorganisasian, pengarahan, dan pengawasan usaha-usaha para anggota organisasi dan penggunaan sumber daya-sumber daya organisasi lainnya agar mencapai tujuan organisasi seperti sistem pengelolaan yang diterapkan grup Sukmo Budaya.

Eksistensi grup musik keroncong Sukmo Budaya dapat bertahan karena memiliki satu tujuan yang sama dari semua, yaitu tekad untuk melestarikan musik keroncong di desa Sukorejo kecamatan Tegowanu kabupaten Grobogan, hingga saat ini grup Sukmo Budaya hanya menerima panggilan untuk mengisi acara hanya dikawasan kabupaten Grobogan dan sekitarnya.

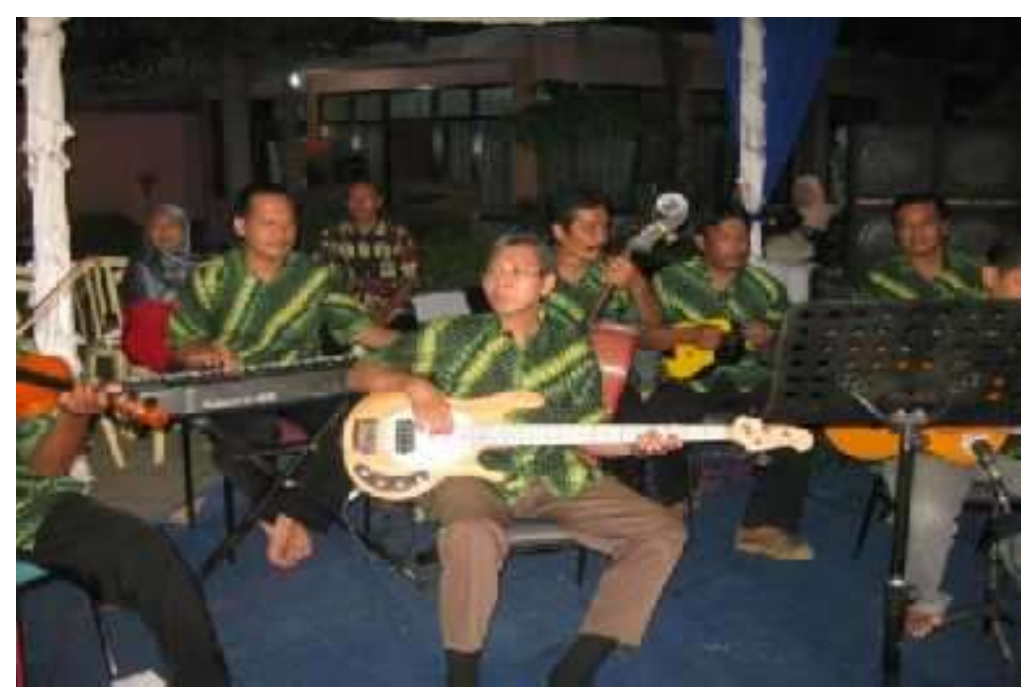

Gambar 1. Grup keroncong sukmo budaya saat pentas (doc: Dani Nur Saputra, 2016) 
Manajemen pengarahan ditunjukkan melalui latihan grup musik keroncong Sukmo Budaya rutin dilaksanakan seminggu sekali yaitu pada hari Sabtu pukul 20.00 sampai 23.00. Proses latihan grup keroncong Sukmo Budaya juga dijadikan sarana silahturahmi dari setiap personil juga masyarakat setempat. Pejabat desa sering menjadi tamu undangan seperti kepala desa Gedungmulya yaitu bapak Budi Istanto untuk hadir dan menyumbangkan suara dengan diiringi grup Sukmo Budaya. Tempat pelatihan rutin grup keroncong Sukmo Budaya dilakukan di rumah Bapak Muhaimin yang menjadi salah satu anggota grup.

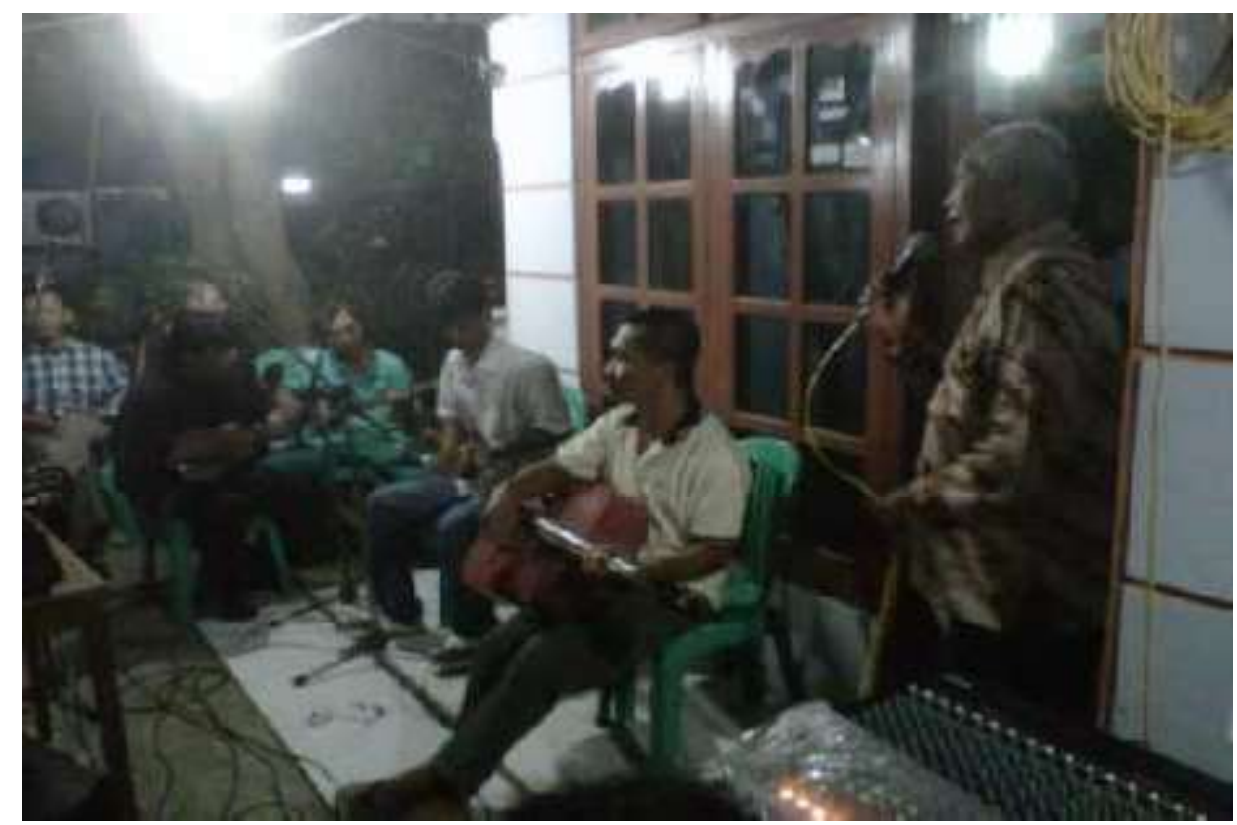

Gambar 2. Foto saat latihan rutin musik keroncong (doc: Dani Nur Saputra, 2016)

\section{Ciri Khas}

Grup keroncong Sukmo Budaya dalam setiap penampilannya selalu menyajikan dengan gaya khas penyanyi yang selalu mengajak pendengar untuk ikut menyanyi dan mengobrol seputar nostalgia lagu yang sedang dinyanyikan. Kemudian membuka waktu untuk mempersilahkan pendengar menyumbangkan suara mereka dalam sebuah lagu.

Keunikan lain dalam grup keroncong Sukmo Budaya terdapat pada aransemen tiap lagu yang dibawakan. Progesi-progesi akord yang bervariatif memunculkan nilai keindahan dalam setiap penampilan. Hal ini memang menambah keharmonisan musik keroncong namun di dalam melakukan improvisasi, pemain tidak boleh terlepas dari bentuk irama keroncong dan akord-akord yang terdapat di dalamnya.

Pernyataan tersebut sesuai dengan yang dijelaskan oleh Sanjaya (2008: 6) bahwa saat memainkan improvisasi, instrumen pengiring kemungkinan akan terjadi permainan saat ini akan berbeda dengan permainan pada saat yang lain, hal ini tidak menjadi masalah bagi irama keroncong. Kostum atau seragam yang selalu dipakai dalam setiap 
penampilannya adalah baju batik berwarna hijau yang melambangkan ciri khas mereka kepada masyarakat.

\section{Model Pementasan}

Kehadiran grup musik keroncong Sukmo Budaya mendapat sambutan baik oleh masyarakat desa Sukorejo, kecamatan Tegowanu. Keberadaan grup musik keroncong ini membuat setiap pendengarnya bernostalgia melalui lagu-lagu yang dibawakan oleh grup musik tersebut. Banyak event di desa Sukorejo, kecamatan Tegowanu yang dimeriahkan oleh alunan musik keroncong grup Sukmo Budaya antara lain seperti acara ulang tahun bank, pernikahan atau serah terima jabatan Kapolres Grobogan.

Pertunjukan musik ini dalam penyajiannya terdapat beberapa unsur yang menjadikan hal tersebut menarik untuk dilihat. Pertunjukan musik keroncong grup Sukmo Budaya jika dilihat dari jumlah pemainnya dapat digolongkan sebagai pertunjukan ansembel kecil. Grup ini memadukan beberapa jenis alat musik yang memiliki karakter suara berbeda-beda. Pertunjukan musik keroncong grup Sukmo Budaya dipandu oleh salah satu penyanyi yang merangkap sebagai MC (Master Of Ceremony). Urutan penyajian pertunjukan grup keroncong Sukmo Budaya sebagai berikut.

Tahap pertama yaitu persiapan, sebelum acara dimulai pemimpin grup keroncong Sukmo Budaya memberikan intruksi untuk mengecek semua komponen pertunjukan yang terdiri atas kesiapan alat musik, microphone, sound system, letak tempat duduk pemain dan tempat berdiri untuk penyanyi. Tahap selanjutnya pimpinan grup keroncong Sukmo Budaya memberikan intruksi kepada semua pemain agar mengurutkan lagu yang sudah disiapkan sejak awal, yaitu tujuh lagu, tujuh lagu itu adalah lagu pokok yang akan dibawakan tetapi mereka tetap menerima permintaan dari penonton yang dibatasi yaitu 4 lagu.

Kedua yaitu pembukaan, penyanyi merangkap sebagai pembawa acara lalu membuka dengan memberikan salam kepada tuan rumah dan tamu undangan sebagai penonton. Kemudian pembawa acara memperkenalkan semua pemain keroncong grup Sukmo Budaya. Ketiga yaitu pertunjukan inti, pertunjukan dimulai dengan memainkan satu lagu yaitu lagu Bengawan Solo.

Setelah membawakan empat lagu yang sudah disusun sendiri oleh grup Sukmo Budaya, pembawa acara mempersilahkan penonton untuk menyumbangkan suaranya. Setelah dua lagu yang diminta penonton selesai dimainkan, mereka melanjutkan memainkan lagu sesuai dengan urutan dari pemimpin grup Sukmo Budaya. Ketika urutan lagu ketujuh sudah dibawakan, penyanyi kembali membuka sesi permintaan lagu dari penonton. Tahap keempat yaitu penutup, setelah pertunjukan musik keroncong grup Sukmo Budaya selesai memainkan semua lagu maka pembawa acara mengucapkan terima kasih kepada penonton dan pihak yang mempunyai acara tersebut.

Tempat pentas atau panggung merupakan sarana penting yang digunakan sebagai tempat berlangsungnya pertunjukan seni baik tari, drama ataupun musik. Letak atau posisi panggung dikondisikan sedemikian rupa dengan maksud agar pemain dapat dengan leluasa melakukan segala kegiatan pertunjukan diatas panggung, sehingga pertunjukan dapat dinikmati dengan nyaman (Hardjana, 1983: 30).

Pernyataan tersebut sesuai dengan pertunjukan grup Sukmo Budaya dalam penataan panggungnya sudah diatur sedemikian rupa, formasi tempat duduk personil dan letak penyanyi sudah ditentukan sejak latihan. Sebelum pentas pemimpin dari grup keroncong 
Sukmo Budaya sudah menjalin kesepakatan dengan pihak panitia akan bentuk dan letak panggung yang disediakan.

Setiap pertunjukan tidak hanya tampilan yang dapat dilihat mata saja, tapi keindahan suara dari setiap nada yang dikeluarkan oleh pemain harus diperhatikan. Penataan suara dari pertunjukan grup keroncong Sukmo Budaya memakai sound system lengkap yaitu mixer, sound, kabel dan mikrophone.

Output beberapa alat musik tidak langsung mengunakan kabel instrumen yang disambungkan dari mixer langsung ke alat musik, tapi menggunakan mikrofon yang didekatkan dengan sumber suara alat musik tersebut, contohnya: cak, cuk, gitar dan cello bass. Contra bass, biola, dan keyboard disambungkan langsung oleh kabel instrumen ke mixer. Bagian tersulit dari pengaturan mixer adalah memadukan dua hal tersebut diatas, karena terkadang mikrophone untuk alat musik tergeser, jadi suara kadang tidak terdengar, maka mixer menambah volume bagian alat musik yang mikrophonenya tergeser.

\section{Gaya Keroncong}

Menurut Kusbini (1970: 23) Seorang penyanyi mempunyai gaya dan pembawaan lagu yang tersendiri. Hal ini juga berlaku bagi setiap penyanyi lagu-lagu keroncong. Disamping mempunyai gaya yang tersendiri untuk menyanyikan lagu-lagu keroncong, diperlukan penguasaan terhadap gaya dan lekukan-lekukan yang khas.

Penulisan lagu-lagu keroncong, biasanya pencipta lagu tidak menyertakan tandatanda lekuk maupun dinamika seperti halnya penulisan lagu-lagu seriosa. Hal ini karena komponis lagu-lagu keroncong yang terdahulu kurang memperhatikan tentang tulisan lagu-lagu ciptaannya, sehingga penyanyi itu sendirilah yang harus mengolah dan menghayati jiwa lagu-lagu tersebut. Selain gaya dan lekuk-lekuk keroncong, tehnik lain yang perlu diketahui yaitu: bernyanyi secara ngandul (ioan-maatig). Bernyanyi secara ngegantung maat itu banyak disukai oleh beberapa penyanyi keroncong, tidak dipersalahkan asal saja tidak melewati terlalu banyak birama yang telah ditentukan (Budiman, 1997: 16).

Beberapa alat musik yang digunakan dalam pertunjukan grup tersebut diantaranya biola. Biola bertugas mengisi melodi dalam setiap irama musik keroncong yang terletak pada introduksi, isian, coda dan ending. Selanjutnya cello, cello dimainkan dengan cara dipetik (pizzicato), biasanya dipetik dengan jari telunjuk dan ibu jari. Irama keroncong cello memainkan tiga sampai empat nada yang dipetik secara bergantian, atau paling sedikit dua nada dalam satu akordnya. Permainan cello petik sebetulnya mementingkan permainan individu yang kuat, sebab cello dalam irama keroncong bertugas sebagai gendang (Budiman, 1997: 21).

Pada irama keroncong, bass hanya memainkan nada akord dan contranya, diperbolehkan apabila pada waktu tertentu membunyikan nada terts akord yang dimainkanya. Hal ini terjadi, apabila beberapa birama hanya memainkan satu akord saja dan agar tidak menjemukan bisa melakukan variasi dengan merangkainya dengan nada yang lain atau nada-nada yang terdekat. 
Alat selanjutnya ialah gitar, gitar dibagi menjadi 2 yaitu cuk (ukulele) dan cak (banyo), melodi untuk irama keroncong mempergunakan not 1/16 pada irama engkel dan $1 / 32$ pada irama double. Cara memetik biasanya dengan menggunakan tokel (alat pemetik gitar yang terbuat dari plastik; plektrum). Terdapat dua bentuk permainan ukulele yaitu ukulele yang dimainkan dengan petikan jari tangan dan yang menggunakan tokel, untuk memainkan banyo tidak begitu berbeda dengan cara memainkan ukulele, hanya pukulannya harus berlawanan dengan pukulan ukulele, pukulan banyo berpola singkop. Selain pukulan singkop ada juga yang memainkan dengan dipetik satu per satu seperti ukulele.

Jenis lagu keroncong yang dimainkan oleh grup musik Sukmo Budaya, terdiri dari tiga, yaitu: (1) keroncong asli, (2) langgam keroncong, (3) stambul I/ stambul II. Hal tersebut sesuai dengan yang diungkapkan oleh Budiman 1997: 14. Secara rinci penjelasan dari masing-masing jenis lagu keroncong adalah sebagai berikut:

\section{Keroncong Asli}

Pengenalan kembali lagu-lagu Keroncong Asli tempo yang memiliki repertoire adalah sangat sulit. Lagu-lagu keroncong asli ini dahulu tidak ditulis, tetapi diturunkan secara lisan. Setelah mengalami perkembangan barulah repertoire lagu-lagu Keroncong Asli ini ditulis antara lain oleh Kusbini, seorang komponis dan penyanyi keroncong dari Surabaya yang mendapat julukan "Buaya Keroncong".

Lagu keroncong asli yang dibawakan grup ini sesuai pernyataan dari (Harmunah 1997: 6) menyatakan bahwa Bentuk, harmonisasi, dan pembawaan yang khas dari Keroncong asli adalah sebagai berikut: (a) dalam tangganada mayor, (b) tanda sukat $4 / 4$, (c) panjang 28 birama, (d) birama tanpa intro dan coda, (e) bentuk kalimat $\mathrm{A}-\mathrm{B}-\mathrm{C}$, dinyanyikan dua kali, (f) introduksi secara improvisatoris, (g) pada tengah lagu ada interlude, yaitu pada birama kesembilan dan kesepuluh, (h) coda, berupa kadens lengkap, (i) bersyair secara improvisatoris.

Harmonisasi keroncong asli sebagai berikut:

$$
\begin{aligned}
& \text { A } \quad I \ldots I \ldots V \ldots V \ldots 4 \\
& \text { II . . II . . . V . . V . . . } 4 \\
& \text { V ... V ..B IV ... IV ... } 4 \\
& \text { interlude } \\
& \text { IV ... IV . V . I . . I . . } 4 \\
& \text { V... V ... I ...IV.V. } 4 \\
& \text { C I... IV.V.I ...I.. } 4 \\
& \text { V... V...I...I.. } 4 \\
& \text { Coda } 28 \text { birama } \\
& \text { Contoh: "Bakti Pemuda" ciptaan Tjoek.S }
\end{aligned}
$$

\section{Langgam}

Menurut Kurniasih (2006: 7) langgam mempunyai bentuk, harmonisasi, dan pembawaan sebagai berikut: (a) dalam tangganada mayor dan tangganada yang diarahkan dari musik 
daerah, (b) tanda sukat 4/4, (c) panjang lagu 32 birama tanpa intro dan coda, (d) bentuk kalimat, A - A - B - A, (e) lagu dibawakan dua kali, ulangan kalimat A dibawakan secara instrumental, vokal baru masuk pada kalimat B, dan dilanjutkan kalimat A, (f) introduksi biasanya diambilkan empat birama terakhir dari lagu langgam tersebut, dan $(\mathrm{g})$ coda berupa kadens lengkap. Analisis tentang harmonisasi dalam lagu keroncong yang dibawakan grup Sukmo Budaya adalah sebagai berikut,

Introduksi
A $\quad$ I ... IV .V. I ... I . . 4
V ... V . . I I . I I . . 4
A $\quad$ I ... IV . V. I ... I . . 4
V ... V ... I I.. I . . 4
B $\quad$ IV ...IV ... I . . I I . 4
C o d a. $\quad 32$ birama
Contoh: Langgam "Bengawan Solo" ciptaan Gesang

\section{Stambul}

Stambul terdiri dari dua bentuk yaitu: Stambul I dan Stambul II, Stambul I menurut Harmunah (1997: 7) ciri-ciri khas bentuk harmonisasi dan pembawaannya, adalah sebagai berikut: (a) dalam tangganada mayor, (b) tanda sukat 4/4, (c) panjang 16 birama tanpa intro dan coda, (d) bentuk kalimat, A - B, (e) bersyair secara improvisatoris, (f) introduksi merupakan improvisasi dengan peralihan pada akord Tonika ke akord Sub Dominan, (g) sering berbentuk musik dan vokal saling

Stambul II menurut Sanjaya (1997: 8) ciri-ciri khas bentuk harmonisasi dan pembawaannya, adalah sebagai berikut: (a) dalam tangganada mayor, (b) tanda sukat $4 / 4$, (c) panjang dua kali 16 birama, (d) bentuk kalimat, A - B, (e) bersyair secara improvisatoris, (f) introduksi merupakan improvisasi dengan peralihan dari akor tonika ke akor sub dominan, sering berupa vokal yang dinyanyikan secara recitatife dengan peralihan akor I ke akord IV, tanpa iringan.

Penjelasan yang dikemukakan oleh dua ahli tersebut sejalan dengan stambul yang dimainkan oleh grup musik ini. Hasil analisa dari stambul I dan stambul II adalah sebagai berikut.

\section{Harmonisasi Stambul I:}

Introduksi

$$
\begin{aligned}
& \text { A } \quad \text { IV } \ldots \text { IV } \ldots . \text { I } \ldots \text { I } \ldots 4
\end{aligned}
$$

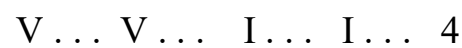

$$
\begin{aligned}
& \text { B } \quad \text { IV } \ldots \text { IV } \ldots . \text { I } \ldots \text { I } \ldots 4 \\
& \text { V ... V . . I . . I . . } 4
\end{aligned}
$$

Cod a.

Contoh : stambul "Jangan Mengharap" ciptaan Tjoek S 
Harmonisasi Stambul II:

Introduksi

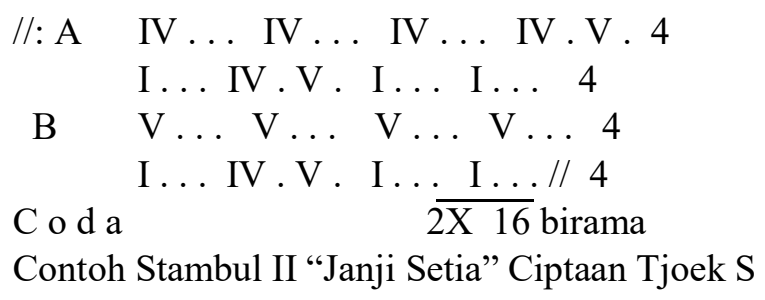

\section{Pembahasan}

Warga desa Sukorejo sangat antusias dengan musik keroncong dibandingkan dengan desa-desa lain di Kecamatan Tegowanu, irama musik keroncong terdengar lebih kental di tengah-tengah pergaulan sosial warga desa Sukorejo. Musik keroncong sudah lama dikenal warga desa Sukorejo sejak puluhan tahun yang lalu. Meskipun sempat mengalami penurunan, namun sejak pertengahan tahun 2000 musik keroncong mulai hadir kembali di hati warga desa Sukorejo. Pada era sekarang ini musik keroncong masih diminati walau hanya beberapa daerah terutama di kabupaten Grobogan yang sebagian besar masyarakat menjadikan musik dangdut sebagai hiburan yang dominan di tengah masyarakat.

Hasil temuan lain berdasarkan analisis terhadap keeksitensian grup musik keroncong Sukmo Budaya yaitu pengaruh atau dampak psikis yang terjadi pada masyarakat desa Sukorejo. Pengaruh positif dari kehadiran grup musik ini adalah salah satu faktor bahwa grup Sukmo Budaya tetap eksis karena dapat menjadi hiburan yang berdampak pada psikis mereka. Lima lansia dari warga masyarakat mengungkapkan bahwa mereka memiliki perubahan emosional yang lebih baik sejak kehadiran grup musik Sukmo Budaya di desa Sukorejo.

Para lansia ini merasakan bahagia dan tidak mudah stres dalam menyikapi kehidupan menjelang hari tuanya. Menurut mereka, grup tersebut menghibur masyarakat khususnya lansia karena dapat menjadi wadah untuk mengekspresikan perasaan. Mereka juga dapat bernostalgia dengan lagu yang dibawakan sehingga dapat mengingat kembali masa muda yang penuh dengan semangat. Pernyataan tersebut selaras dengan ungkapan bahwa

"musik juga dikaitkan dengan aktivitas dan membawa efek psikologis misalnya mendengarkan musik setelah pulang dari kantor dapat menghilangkan stres pekerjaan" (Djohan 2009:7).

\section{Kesimpulan}

Musik keroncong yang dibawakan oleh grup musik Sukmo Budaya mampu menunjukkan eksistensinya di daerah Grobogan dan bersaing dengan jenis musik dangdut yang mendominasi kawasan tersebut. Grup musik tersebut dapat eksis karena dipengaruhi faktor-faktor yang mendukung eksistensinya antara lain managemen grup, ciri khas, panggilan pentas, bentuk penyajian, panggung, tata suara, tehnik bernyanyi keroncong, penggunaan alat musik, jenis lagu keroncong dan antusias masyarakat terhadap grup 
musik keroncong ini. Hal ini terbukti bahwa grup musik tersebut masih tetap memainkan lagu keroncong untuk memenuhi undangan pentas dan acara-acara resmi di daerah tersebut.

Eksistensi grup Sukmo Budaya memiliki sumbangsih bagi warga masyarakat desa Sukorejo yang ditunjukkan dengan adanya dampak psikis seperti perasaan kenyamanan khususnya bagi para lansia yang menikmati musik keroncong tersebut. Eksistensi musik keroncong yang dibawakan oleh grup tersebut mampu memperlihatkan bahwa musik keroncong dapat dilestarikan sebagai budaya lokal di tengah perkembangan masyarakat modern.

\section{KEPUSTAKAAN}

Abidin, Zainal. 2006. Filsafat Manusia.Bandung: PT.Remaja Rosdakarya.

Agus Bing.2008.“Marco Manardi: Pioner Keroncong Inovatif”.dalam jurnal Gong,edisi 05/IX/2008.

Akbar, Neo. 2013. Perkembangan Musik Keroncong di Surakarta tahun 1920-1970. Yogyakarta: Universitas Negeri Yogyakarta, 2013.

Budiman B.J. 1997. Mengenal Keroncong dari Dekat. Jakarta: Akademi Musik Lembaga Pendidikan Kesenian Jakarta.

Djohan. 2009. Respons Emosi Musikal.Yogyakarta: Lubuk Agung.

Drijastuti. 2013. Eksistensi Keroncong dalam Musik Industri di Indonesia Sebuah Tinjauan Kritis. Yogyakarta: Universitas Gadjah Mada, 2013.

Hardjana, S. 1983. Estetika Musik. Jakarta: Depdikbud.

Harmunah. 1997. Perkembangan Musik Keroncong di Indonesia. Yogyakarta:Departemen Pendidikan dan Kebudayaan.

Jamalus. 1998. Pengajaran Musik Melalui Pengalaman Musik. Jakarta:Depdikbud. Kusbini, 1970. Sejarah Kehidupan, Perkembangan, dan Asal Usul Keroncong Indonesia, Yogyakarta: Sanggar Olah Seni Indonesia (SOSI).

Kusuma, Halim Perdana. 2015. Geliat Eksistensi Musik Keroncong Tugu Kecamatan Koja, Jakarta Utara. Yogyakarta: Universitas Gadjah Mada,2013

Poerwadarminta, W.J.S. 1998. Kamus Besar Bahasa Indonesia. Jakarta: Balai Pustaka.

Sanjaya, Singgih. 2008. Penyusunan Aransemen dalam Musik Keroncong. Bogor:Departemen Pendidikan dan Kebudayaan.

Sari (2010) dalam ejournal.unesa.ac.id/article/15182/38/

Weiss, Mitch dan Pery. 2005. Managing Artist in Pop Music, Jakarta: PT Gramedia Pustaka Umum.

Yampolsky, Philip. 2001. Can The Traditional Arts Survive, and Should They?.

Asian Music: Winter. Apr 2001: 71: Arts \& Humanities Database Journal pg. 175. 